\title{
Brexit: Is Britain Coupable?
}

\section{Hyung Bok Chae*}

In a referendum on June 23, 2016: 51.9 percent of the British electorate voted in favor of the UK's withdrawal (Brexit) from the EU. The reasons are varied, and many were surprised by such 'unintended consequences.' However, Britain is setting a new global strategy to escape the regionalism of integrated Europe by choosing traditional 'splendid isolation.' Nonetheless, Britain could not immediately leave the EU; it must first conclude a withdrawal agreement in accordance with the procedure in Article 50 of the Treaty on the European Union. In this process, strong opposition within British society will pose great challenges, accompanying numerous other barriers to overcome. Following the Supreme Court ruling on January 24, 2017, the UK government recently completed the required parliamentary approval process before initiating Brexit negotiations with the EU. This paper concludes that Britain is indeed coupable of opting to return to nationalism based on sovereignty rather than peace, coexistence, and solidarity in Europe.

\section{Keywords}

Brexit, United Kingdom, Britain, European Union, Referendum 


\section{Introduction}

On June 23, 2016, British voters made a historic decision by referendum to withdraw from the European Union ("EU") with 51.9 percent votes in favor of Brexit. (Table 1) At that time, most expressed their surprise to these 'unintended consequences.'

Table 1: Results of the Brexit Referendum²

\begin{tabular}{|c|c|c|}
\hline Yes (Leave the EU) & No (Maintain EU membership) & Turnout \\
\hline $51.9 \%$ & $48.1 \%$ & $72.2 \%$ \\
\hline
\end{tabular}

The debate on Brexit was ignited by the election pledge of former Prime Minister David Cameron. In 2013, Cameron pledged to hold a referendum on the UK leaving the EU. Two years later, on May 7, 2015, the Conservative Party won a clear victory in the general election. During the campaign period, Cameron reiterated his determination to fulfill the pledge. Subsequently, on June 9, 2015, the House of Commons passed the European Union Referendum Act $(2015)^{3}$ for holding a referendum on the UK's withdrawal from the EU by a landslide vote of 544 to 53 .

Despite this decision, the British showed sharply divided opinions on Brexit. Britain had to suffer severe internal disturbances due to extreme political and social conflicts and confrontations. On June 16, 2016, a week before the referendum, a member of the Labor Party, Helen Joanne (Jo) Cox, who was strongly opposed to Brexit, died after being shot and stabbed multiple times by a right-wing fanatic. This incident seemed to trigger a surge in British public opposition to Brexit. However, even her tragic death did not decisively turn the direction of the British public opinion against Brexit. In the referendum on June 23, against all expectations, more than half of the British electorate voted in favor of Brexit.

The referendum's results sent shockwaves not only through the British community, but also through the other $27 \mathrm{EU}$ member States and countries around the world. British citizens who opposed for Brexit, accused Cameron for the situation

1 See A Symposium of Views: Brexit: The Unintended Consequences, InT'L Economy 6 (2016), available at http://www. international-economy.com/TIE_Sp16_BrexitSymp.pdf(last visited on Apr. 10, 2017).

2 See EU Referendum Results, BBC NEws, available at http://www.bbc.com/news/politics/eu_referendum/results (last visited on Apr. 10, 2017).

3 The National Archives, European Union Referendum Act 2015, 2015 c. 36, available at http://www.legislation.gov.uk/ ukpga/2015/36/enacted (last visited on Apr. 10, 2017). 
and demanded the resignation of him by taking all the responisibilities for the consequences. On June 24, the day after the referendum, Cameron immediately revealed his decision to resign. This led to the prompt commencement of the procedure for appointing a new prime minister. On July 13, Theresa May finally took the office.

Soon after her inauguration, Prime Minister May announced that the UK government would notify the European Council of its withdrawal from the EU by the end of March 2017. However, several Brexit opponents filed a suit, with Mishcon de Reya, one of the UK's largest law firms. The British Supreme Court ruled in favor of the claimants, which put a brake on the government's Brexit process, portending heated debates ahead both inside and outside Britain.

Following the situation, this study will discuss whether Britain is coupable of having a decision to leave the EU. This paper is composed of five parts including a short Introduction and Conclusion. Part two will analyze the reasons why the British sought Brexit. Part three will examine the key issues related to the UK's withdrawal from the EU after the referendum. Brexit has many implications for the expansion and advancement of European integration. Part four will discuss the future orientation of the European Single Market. Finally, Part five will conclude whether Britain, which chose Brexit through a referendum, is indeed responsible for the aftereffects of their decision.

\section{Why the British Want Brexit?}

\section{A. A Love-Hate and Honeymoon Relationship}

In the process of European integration, the relationship between the UK and EU can be defined as "a love-hate and honeymoon relationship." The UK took a stand against the launch of the European Economic Community ("EEC") in 1958. It has also repeatedly shown a lukewarm attitude to the reservations about the policies adopted by the European authorities even after joining the EU. The following are three examples of such a stance.

First, Britain took a vague position on European integration, which was accelerated with the establishment of the European Coal and Steel Community ("ECSC") in 1953, and the EEC and the European Atomic Energy Community ("EAEC" or Euratom) in 1958. Pressured by perceptions of crisis and urgency, Britain formed the European Free Trade Association ("EFTA") on May 3, 1960, along with six other European 
countries (Austria, Sweden, Switzerland, Denmark, Norway, and Portugal). However, the development of EFTA, led by the UK, was sluggish compared to that of the EEC, which had been making continued progress in the expansion and advancement of European integration. In the meantime, Britain and Denmark joined the EEC in 1973; followed by Portugal in 1986, and Austria, Sweden, and Finland in 1995. EFTA, which had been barely surviving due to the withdrawals of most of its members, signed an agreement with the EU in 1994 to establish the European Economic Area ("EEA"). ${ }^{4}$

In the beginning, Britain not only opposed European integration, but also formed EFTA to counter the EEC. Within a few years, however, the UK joined the EEC and repeatedly took confusing positions toward European integration.

Second, the UK has also shown an ambiguity or a quite confusing stance toward the EU's policies. A typical example is the UK's referendum on withdrawal from the EEC held in 1975. Holding this vote was rather surprising as it came only two years after the UK joined the Community. With 67.23 percent of votes for maintaining the membership and 32.77 percent for leaving, Britain, thus decided to remain in the EEC. ${ }^{5}$ Thus, the Brexit referendum in 2016 conveys a sense of deja vu of the 1975 vote.

Third, the UK, which has taken separate actions since the early years of its EEC membership, often opposed the EU's policies or exercises reservations. E.g., it did not join the Eurozone ${ }^{6}$ and the Schengen Agreement. ${ }^{7}$ The UK has continued to take steps that deviate from European integration, taking a passive or negative stance toward policies deemed contrary to its interests or demanding an exception to the implementation of such policies.

4 As of January 2017, EFTA has four member States such as Iceland, Norway, Switzerland and Liechtenstein. For details on the brief history of EFTA, see EFTA, EFTA States, available at http://www.efta.int/about-efta/the-efta-states (last visited on Apr. 10, 2017).

5 K. McCray, Brexit, An Analysis of Eurosceptic Mobilisation and the British Vote to Leave the European Union (unpublished thesis, University Honors College) 34 (Fall 2016) (on file with the author), available at http://jewlscholar. mtsu.edu/bitstream/handle/mtsu/5092/McCrary\%20Thesis.pdf?sequence=1 (last visited on Apr. 10, 2017).

6 The eurozone, which uses a single currency, was introduced by the Mastricht Treaty. See Article B, Title I: Common Provisions of the Treaty of Maastricht. However, Britain did not join a single currency through the "Protocol on Certain Provisions Relating to the United Kingdom of Great Britain and Northern Ireland. "Paragraph 4 of this Protocol stipulated that: "The United Kingdom shall retain its powers in the field of monetary policy according to national law."

7 The Schengen Agreement was signed in 1985 between Belgium, France, the Federal Republic of Germany, Luxembourg and the Netherlands. Today, the Schengen Area consists of 26 European countries ( 22 of which are EU member States). However, the UK is not a part of Schengen area. See European Commission, Europe without borders: The Schengen area, at 4, available at $\mathrm{http} / /$ ec.europa.eu/home-affairs/sites/homeaffairs/files/e-library/docs/schengen brochure/schengen_brochure_dr3111126_en.pdf(last visited on Apr. 10, 2017). 


\section{B. Disapproval of the EU Bureaucracy}

The UK's decision on Brexit is also a result of its disapproval of the EU bureaucracy. This can be discussed in several aspects. First, the EU comprises numerous organizations, including seven major institutions: the European Commission, European Council, Council or EU Council, European Parliament, Court of Justice of the European Union ("ECJ"), European Court of Auditors, and European Central Bank. Most of the staff working for these institutions, known as EU officials, are nonelective. In particular, there has been considerable criticism over the bureaucracy (or bureaucratization) of the European Commission. ${ }^{8}$

The criticism is mainly against the right to legislative initiative held by the European Commission in the EU's legislative process. Although elective officials from member States and the Members of the European Paliament elected through direct elections debate, revise, and pass a bill, this process can merely amend the bills introduced by the European Commission. This is why critics have repeatedly asserted that the unelected European Commission truly leads the EU, even if it does not have legislative power. ${ }^{9}$

At the EU level, the harmonization and coordination mechanisms ${ }^{10}$ have been applied to solve the problems of conflicts and contradictions among the EU laws, and between the domestic laws of the Member States, led by the European Commission and Council. From the British perspective, however, even if these mechanisms are working, the EU laws and policies, which have a profound impact, are primarily established and implemented by the EU bureaucrats. This allows them to exercise a great influence over the UK, which has a relatively small number of bureaucrats and, thus, disapproves of the EU bureaucracy.

Second, there would be confrontations and conflicts between the EU law, based

8 High Level Group on Administrative Burdens, Cutting Red Tape in Europe: Legacy and outlook (Final Report), (July 24, 2014), available at http://ec.europa.eu/smart-regulation/refit/admin_burden/docs/08-10web_cebrocuttingredtape_en.pdf(last visited on Apr. 10, 2017).

9 For details on two opposing views on the European Commission, see EU facts behind the claims: 'Brussels bureaucrats, (Apr. 25, 2016), available at https://fullfact.org/europe/eu-facts-behind-claims-brussels-bureaucrats (last visited on Apr. 10, 2017).

10 New laws and policies of the EU are coordinated through review procedures to resolve conflicts and contradictions with other (EU) laws and policies already in place. These are called 'harmonization procedures.' In addition, there can also be conflicts and contradictions between EU laws and policies and the national laws and policies of EU member States. To solve this problem, 'coordination procedures' can be implemented. For details on the mechanisms of the harmonization and coordination procedures in the case of tax policies, see L. Kouba, M. Mádr, D. Nerudová \& P. Rozmahel, Policy autonomy, coordination or harmonization in the persistently heterogeneous European Union?, Work Package 403 MS79: Working Paper No. 95 (Apr. 2015), available at http://www.foreurope.eu/fileadmin/documents/ pdf/Workingpapers/WWWforEurope_WPS_no095_MS79.pdf(last visited on Apr. 10, 2017). 
on civil law systems of continental Europe, and the British law, based on the common law (Anglo-American) system. In accordance with the primacy principle and the principles of direct applicability and direct effect, the UK's domestic law is bound by EU law. However, the overall EU legal system is based on civil law, centered on France and Germany. Except for the UK and Ireland, who share common law, the EU's members have, in principle, adopted civil law. In terms of the total number of employees working in EU organizations, the number of British citizens is relatively small. Therefore, the EU law, based on civil law, might operate to the disadvantage of the UK in terms of the interpretation and application of laws and thus the establishment of policies. Accordingly, the UK is dissatisfied with its position not properly reflected in all these processes. ${ }^{11}$

Third, there is a conflict between the UK and the EU over immigration and refugee policies and contributions. In the 1990s, the proportion of immigrants in the UK was 5 percent, but it has recently surpassed 13 percent. ${ }^{12}$ In particular, workers in the EU member States with relatively low labor costs, such as Poland and Portugal, are increasingly moving to the UK where they can be better paid. Consequently, there have been increasing complaints from the British that immigrants are taking their jobs. ${ }^{13}$ This negative public opinion, however, overlooked the fact that immigrants are contributing the UK's economy by paying more taxes and receiving less in welfare benefits than the innate British. In the meantime, anti-EU sentiment in the UK spread rapidly as the country became increasingly confronted by Germany and France over the acceptance of Syrian refugees in Europe. ${ }^{14}$ Moreover, although Britain is the third largest financial contributor following Germany and France, ${ }^{15}$ there have been

11 As of January 1, 2017, e.g., the number of the UK employees working for the European Commission is only 597. Other nationalities are as follows: 763(Poland), 1,058(Spain), 1,314(Belgium), 1,330(France), 1,373(Germany), 1,387(Italy). See European Commission, Statistical Bulletin for COMMISSION on 01/01/2017, available at http://ec.europa.eu/ civil_service/docs/europa_sp2_bs_nat_x_grade_en.pdf (last visited on Apr. 10, 2017).

12 As of January 1, 2015, the numbers of immigrants from third countries (non-member States) residing in the EU were 7.5 million in Germany, 5.4 million in Britain, 5 million in Italy, 4.5 million in Spain, and 4.4 million in France. The total number of immigrants in the five member States represents 76 percent of the total immigrants in the EU and 63 percent of the non-nationals population of the $28 \mathrm{EU}$ member States. For details, see Eurostat Statistics Explained, Migration and Migrant Population Statistics (May 2016), available at http://ec.europa.eu/eurostat/statistics-explained/ index.php/Migration_and_migrant_population_statistics (last visited on Apr. 10, 2017).

13 According to the Migration Observatory research team at Oxford University, 49 percent was from Poland and Romania, while Spain, Italy and Portugal accounted for 24 percent of the 700,000 to 3.3 million during 2011-15. Leave campaigners insisted on full control of its border to protect British workers' jobs. See Eurozone crisis 'pushing migrants to UK,' BBC News, Apr. 13, 2016, available at http://www.bbc.com/news/uk-36029703 (last visited on Apr. 10, 2017).

14 See How is the migrant crisis dividing EU countries?, BBC News, Mar. 4, 2016, available at http://www.bbc.com/ news/world-europe-34278886 (last visited on Apr. 10, 2017).

15 The contributions of member States provide most of the EU's budget. As of January 1, 2015, the four countries such as Germany $(21.36 \%)$, France $(15.72 \%)$, the UK $(12.57 \%)$, and Italy $(11.48 \%)$ paid more than 10 percent of the 
considerable complaints that the country has not proportionately benefited from its EU membership. ${ }^{16}$ It is also considered that, amidst a high unemployment rate and economic recession in the UK, a large amount of its EU contributions were used to support Greece in the economic crisis. Such growing dissatisfaction also affected Britain's decision on Brexit. ${ }^{17}$

\section{Integrationism through the Expansion of Europe}

Some media sources have analyzed Britain's decision to withdraw from the EU from the standpoint of isolationism and Euroskepticism. ${ }^{18}$ The European integration has made national borders meaningless in many aspects, bringing the "retreat of the state." However, the British perceived it as an infringement of 'territorial sovereignty.' In this situation, Britain chose 'splendid isolation,' which "does not directly engage in the affairs of the continent of Europe or form an alliance with any country.","

Britain has often confronted and conflicted with the continental Europe such as Germany and France, as seen in the attempted German invasion of the UK during World War II and the UK's disapproval of the EEC at the time of its foundation, which it only joined much later. In addition, its recent attitudes toward the immigration and anti-terrorism policies promoted by the European authorities demonstrate that the UK has maintained its position as an opponent, rather than an active partner

EU budget. See Statista: The Statistics Portal, Share of total contributions to the European Union budget in 2015, by Member State, available at https://www.statista.com/statistics/316691/european-union-eu-budget-share-ofcontributions (last visited on Apr. 10, 2017).

16 However, it cannot be asserted that the UK receives no benefit in return for its contributions. The UK has received various subsidies from the EU, including the support from the Common Agricultural Policy and funding for domestic economic development and scientific research and development. Britain is the third largest country, after Germany and France, in terms of the absolute amount of the EU budget contributions, but its share is the eighth largest when converted to a per capita figure. In the process of debating Brexit, the UK government was criticized for not providing the people with accurate information related to these contributions. See The UK in a Changing Europe, The EU budget - a tough nut for the UK?, available at http://ukandeu.ac.uk/explainers/the-eu-budget-a-tough-nut-for-the-uk-3 (last visited on Apr. 10, 2017).

17 For critical views on Britain's pay to bail-out Greece, see Greece crisis: Treasury backs use of UK cash to help kickstart Athens' economy, RT NEws, July 15, 2015, available at https://www.rt.com/uk/273760-greece-britain-money-loan (last visited on Apr. 10, 2017).

18 M. Boot, Brexit: Isolationism or Atlanticism?, Comment. MAG., June 27, 2016, available at https://www. commentarymagazine.com/foreign-policy/europe/brexit-isolationism-atlanticism. See also O. Wright, Euroscepticism on the rise across Europe as analysis finds increasing opposition to the EU in France, Germany and Spain, INDEPENDENT, June 7, 2016, available at http://www.independent.co.uk/news/world/europe/euroscepticism-on-the-rise-across-europeas-analysis-finds-increasing-opposition-to-the-eu-in-france-a7069766.html (last visited on Apr. 10, 2017).

19 I. Buruma, The End of the Anglo-American Order, N.Y. Times, Nov. 29, 2016, available at https://www.nytimes. com/2016/11/29/magazine/the-end-of-the-anglo-american-order.html?_r=0 (last visited on Apr. 10, 2017). 
(or helper), in European integration since joining the EC (EU). ${ }^{20}$ Ultimately, Britain has opted to break free from the EU, which has continuously interfered with its sovereignty, by choosing isolation. It now seeks to develop a more constructive global strategy with members of the Commonwealth Nations and other longstanding allies such as the US, Canada, Australia, New Zealand.

\section{Issues Related to the UK's Withdrawal after the Referendum}

\section{A. Legal Basis of the Referendum on Brexit: Article 50, Section 1 of TEU}

The legal basis of a referendum to withdraw from the EU is Article 50, Section 1 of the Treaty on the European Union ("TEU"), as amended by the Treaty of Lisbon. It stipulates: "Every Member State may decide to withdraw from the Union in accordance with its constitutional requirements," opening the possibility of voluntary withdrawal. The introduction of this provision in 2009 marked a significant step forward from the existing basic treaties, which contained no provisions for member States seeking to withdraw from the EU. ${ }^{21}$

The withdrawal procedure is relatively simple: (1) If any member state seeking to withdraw notifies the European Council of its intention; (2) the European Council negotiates and concludes an agreement with that state. That agreement shall be

20 In November 2015, former Prime Minister Cameron made the following four requests to the EU: (1) to guarantee the UK's access to the European single market while establishing safeguards for it as a non-eurozone country; (2) to recognize the right to reject laws enacted by the European Parliament if individual EU member States do not want to accept them; (3) to reduce regulations to strengthen the EU's competitiveness; and (4) to ensure the reduction of immigrant welfare. See A New Settlement for the United Kingdom in A Reformed European Union, Nov. 10, 2015, available at https://www.gov.uk/government/uploads/system/uploads/attachment_data/file/475679/Donald_Tusk_ letter.pdf. The EU accepted these requests and, on February 18-19, 2016, adopted a UK-EU agreement entitled, "A New Settlement for the United Kingdom within the European Union (2016/C69 I/01)." The main contents of the agreement were as follows: (1) opposing ever-closer union; (2) ensuring the access of non-eurozone countries to the eurozone market; (3) introducing a 'red card' system to allow member states to reject or amend laws enacted by the $\mathrm{EU}$; and (4) recognizing the rights of member States to limit welfare for immigrants and block immigration in case of emergency. See EUR-Lex: Access to European Union Law, available at http://eur-lex.europa.eu/legal-content/EN/ TXT/?uri=OJ\%3AJOC_2016_069_I_0001 (all last visited on Apr. 10, 2017). The EU, thus, tried to prevent the UK's withdrawal by accepting its demands as the nation's leaving would have a great impact on the European Single Market in many respects. However, it failed to change the minds of the British public.

21 Hyung-BOK CHAE, EuROPEAn INTEGRATION AND THE TREATy OF LisBon [유럽통합과 리스본조약] 65-6 (2015). 
concluded by the EU Council (hereinafter the Council), acting by a qualified majority, after obtaining the consent of the European Parliament. ${ }^{22}$ With the conclusion of the agreement, TEU and the Treaty on the Functioning of the European Union ("TFEU") cease to apply to the state either (1) from the date of entry into force of the withdrawal agreement, or (2) two years after the state notifies the European Council of its intention to withdraw, ${ }^{23}$ unless the European Council, in agreement with the member State concerned, unanimously decides to extend this period. ${ }^{24}$

With regard to the effectuation of withdrawal, the following interpretations are pertinent. First, withdrawal can be completed at any time a member State wants to do so. Officially, the member ceases to be bound by obligations under the Treaty of Lisbon from the date of the announcement of a withdrawal agreement or from the second anniversary of the date on which intention to withdraw is notified. However, it is considered that the member State is, in effect, not bound by these treaty obligations from the time when its intention of withdrawal is notified. Even if the member State pursuing withdrawal does not comply with its obligations under the treaty, it would not be easy to take practical measures against that State to enforce the performance of the obligations. ${ }^{25}$

Second, the European Council can extend the period before withdrawal becomes effective either by unanimity or in agreement with the member State concerned. This means that withdrawal can take effect even if the EU does not agree with the withdrawal of the member State concerned. ${ }^{26}$

Third, the Treaty of Lisbon limits the power of representation of the member of the European Council or of the Council representing the State seeking to withdraw. It means the member of the European Council or the Council representing the withdrawing State cannot participate in the discussions of the European Council or the Council or in decisions concerning it. ${ }^{27}$ Under this limit, although the member of the European Council and the Council can participate in the discussions, but his/her deliberation and voting rights cannot be exercised. Consequently, the member cannot exert the power of representation as representative of the member State concerned at the European Council and the Council.

What if a state that has withdrawn from the Union asks to rejoin? In such a case,

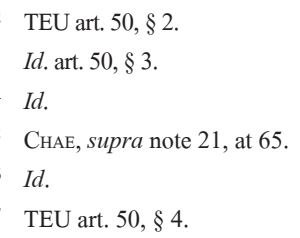


its request is subject to the new membership joining procedure stated in Article 49 of the TEU. ${ }^{28}$

Therefore, the withdrawal procedure will commence on the date when the UK government officially notifies the European Council of its intention to withdraw from the EU. From this point on, negotiations will be initiated to conclude a withdrawal agreement between the EU authorities and the UK government on the terms of withdrawal and future bilateral relations.

The conclusion of a withdrawal agreement through future negotiations will be conducted in accordance with Article 218 of the TFEU on international agreements. The Council will authorize the opening of negotiations, adopt negotiating directives, allowing the signing of agreements, and conclude them. ${ }^{29}$ In this process, because the Council adopts a decision to appoint a member of the European Commission as the EU's negotiator or the head of the EU's negotiating team, the actual negotiations are carried out by the nominated negotiator of the EU. ${ }^{30}$ When the procedure for concluding the withdrawal agreement is completed, as a result of the negotiations, the EU negotiator will submit the proposal to the Council. Based on this proposal, the Council will approve the conclusion of the agreement, ${ }^{31}$ and, if necessary, adopt the agreement after obtaining the consent of the European Parliament. ${ }^{32}$

\section{B. UK-EU Relationship after the Referendum}

As discussed above, in accordance with Article 50 of TEU and Article 218 of TFEU, withdrawal negotiations are initiated after and based on the UK Government's official notification of its intention to withdraw. However, there is still room for conflict.. Although more than half of the British electorate support the Brexit, this situation is a domestic matter within Britain. In other words, there is no change in the status of the UK as an EU member before the UK government officially informs the European Council of its intention to withdraw. The question is how the relationship between the UK and the EU will function in the two-year period from the UK's official notification to the European Council, to the conclusion of a withdrawal agreement and definitive completion of the withdrawal. Regarding this period, Article 50, Section 4 of TEU stipulates:

\footnotetext{
Id. art. $50, \S 5$.

Id. art. $218, \S 2$.

Id. art. $218, \S 3$.

Id. art. $218, \S \S 5 \& 6$.

Id. art. $218, \S 6$.
} 
For the purposes of paragraphs 2 and 3, the member of the European Council or of the Council representing the withdrawing Member State shall not participate in the discussions of the European Council or Council or in decisions concerning it.

Accordingly, from the day the UK government officially notifies the EU of its intention to withdraw, the UK participates in the European Council and the Council, but will not be able to deliberate on agendas or participate in decisions related to them. Although the UK maintains the status of an EU member, it cannot participate in decisions on the general interests of Europe as its exercise of deliberation and voting rights in the European Council and the Council is limited. Overall, the UK and the EU can only maintain business as usual. Of course, as the UK's status as a EU member is retained in the European Commission, the European Parliament, and the ECJ, it can thus participate in the EU legislative initiatives and enactments led by the European Commission and the European Parliament, as well as in litigation before the ECJ. Unlike the European Council and the Council in which the interests of individual member States are directly represented, however, these institutions would act in the general interests of Europe. In any case, the legal and political status of Britain after its official notification is bound to be weakened, which will push the UK government to complete negotiations for the conclusion of a withdrawal agreement.

\section{Possible Reversal of the Referendum Result by the UK Government and Parliament}

Mishcon de Reya, a British law firm filed a lawsuit in a domestic court representing several claimants. They argued that it is illegal for the prime minister to invoke Article 50 of the TEU, the official procedure for opening the EU withdrawal negotiations, without consent from the British Parliament. ${ }^{33}$ With regard to this contention, Secretary of State Oliver Letwin informed the British Parliament that as the royal prerogative granted to the Cabinet could be relied upon to invoke Article 50 of TEU, it was not illegal for the government to do so without parliamentary consent. ${ }^{34}$ The UK government's position was that invoking Article 50 would constitute exercise of its authority to conclude and abolish diplomatic treaties under the prerogative

33 Mishcon de Reya, Article 50 process on Brexit faces legal challenge to ensure parliamentary involvement, July 3, 2016, available at $\mathrm{https}: / / \mathrm{www} . \mathrm{mishcon} . \mathrm{com} / \mathrm{news} /$ firm_news/article_50_process_on_brexit_faces_legal_challenge_to_ ensure_parliamentary_involvement_07_2016 (last visited on Apr. 10, 2017).

34 House of Commons Hansard, Article 50, Column 1255, available at https://hansard.parliament.uk/ commons/2016-11-07/debates/C59A3B55-6FB3-455D-B704-F8B1BF5A5AF5/Article50 (last visited on Apr. 10, 2017). 
entrusted to it by the sovereign (Queen Elizabeth II). ${ }^{35}$ Under this interpretation, the UK government's stance was that it could initiate Brexit negotiations with the EU absent Parliament's consent.

However, the UK High Court ruled on November 3, 2016 that the government must obtain Parliament's approval to invoke Article $50 .^{36}$ The court thereby ruled against the UK government's position, judging that the citizenship granted by the European Communities Act, enacted in 1972 for the UK to join the EEC, can be deprived only by parliamentary approval, and not by exercise of the royal prerogative. ${ }^{37}$ The UK government immediately appealed the decision to the Supreme Court. On January 24, 2017, however, the Supreme Court upheld the High Court's decision, ruling that the government needs parliamentary approval prior to initiating Brexit negotiations. $^{38}$

In accordance with this decision, the UK government introduced a bill for the opening of withdrawal negotiations, entitled "The European Union (Notification of Withdrawal) Act (hereinafter Brexit Act) to the House of Commons,"39 which was voted on the bill and passed it intact by 498 to 114 on February 1, 2017. ${ }^{40}$

The following day, the UK government issued a white paper detailing its strategies for Brexit, entitled “The United Kingdom’s Exit from and new partnership

35 The royal prerogative derives from the authority that an absolute monarch exercises in his/her individual capacity. Historically, the sovereign powers exerted by a monarch and a head of a state were not clearly divided. However, since modern States were formed, the prerogative exercised by monarchs has gradually and increasingly been transferred to the authority of elected heads of state (e.g., prime ministers). This authority has been widely exercised in legislative, judicial, diplomatic, and military areas, including in relation to privilege and immunity. Therefore, where the government tries to implement policies without parliament's consent under the royal prerogative, exercise of this prerogative of prime ministers has frequently caused conflicts with parliament. In 2008, the British Parliament adopted an act to prevent conflicts caused by this prerogative (The Constitutional Reform and Governance Act 2010) and reviewed the actual cases where the prerogative was exercised in the following year (Review of the Executive Royal Prerogative, Oct. 2009). For details, see House of Commons, The Royal Prerogative, SN/PC/03861 (Dec. 30, 2009), available at $\mathrm{http}: / /$ researchbriefings.files.parliament.uk/documents/SN03861/SN03861.pdf (last visited on Apr. 10, 2017).

36 R(Miller) v. Secretary of State for Exiting the European Union, [2016] EWHC 2768 (Admin) (November 3, 2016). The whole text of the ruling can be available at https:/www.judiciary.gov.uk/judgments/r-miller-v-secretary-of-state-forexiting-the-european-union (last visited on Apr. 10, 2017).

37 Id.

$38 \mathrm{R}$ (on the application of Miller and another) (Respondents) v. Secretary of State for Exiting the European Union(Appellant), [2017] UKSC 5 (Jan 24, 2017). The whole text of the ruling can be available at https://www. supremecourt.uk/cases/docs/uksc-2016-0196-judgment.pdf (last visited on Apr. 10, 2017).

39 For details on the content of the Brexit Act and the process of its approval at the British Parliament, see Bill documents - European Union (Notification of Withdrawal) Act 2017, available at http://services.parliament.uk/bills/2016-17/europ eanunionnotificationofwithdrawal/documents.html (last visited on Apr. 10, 2017).

40 House of Commons, Wednesday 1 February 2017, Votes and Proceedings, No. 103, available at https://www. publications.parliament.uk/pa/cm201617/cmvote/170201v01.pdf (last visited on Apr. 10, 2017). 
with the European Union." ${ }^{41}$ In this white paper, the UK government presents twelve major policy agendas to focus on the strengthening of free trade and immigration policies. $^{42}$

Having been approved by the House of Commons, the bill was sent to the House of Lords for its approval on February 20. Unlike the House of Commons, which passed the government's bill intact, the House of Lords added provisions to guarantee the free movement rights of the EU citizens living legally in the UK when the bill is passed. On March 1, the House of Lords voted on this amended bill ${ }^{43}$ and passed it by 358 to 256 . $^{44}$

As the bill was amended by the House of Lords, it needed to be re-approved by the House of Commons.

On March 13, the House of Commons voted on the bill proposed by the government (original bill) and the bill amended by the House of Lords (amended bill). In their adjudication, judges rejected the latter, while passing the former. ${ }^{45}$ On the same day, the House of Lords also accepted the decision of the House of Commons, thereby finally confirming Parliament's approval of the Brexit Act intact, as first introduced by the government. ${ }^{46}$ As a result, the UK government officially announced the withdrawal of the EU membership to the European Council on March 29 and began the Brexit negotiations over two years. ${ }^{47}$

41 See The whole text of the white paper, available at https:/www.gov.uk/government/uploads/system/uploads/ attachment_data/file/589191/The_United_Kingdoms_exit_from_and_partnership_with_the_EU_Web.pdf (last visited on Apr. 10, 2017).

42 The 12 major principles proposed by the white paper are as follows: (1) Providing certainty and clarity; (2) taking control of our own laws; (3) strengthening the union; (4) protecting our strong and historic ties with Ireland and maintaining the common travel area; (5) controlling immigration; (6) securing rights for EU nationals in the UK and UK nationals in the EU; (7) protecting workers' rights; (8) ensuring free trade with European markets; (9) securing new trade agreements with other countries; (10) ensuring the UK remains the best place for science and innovation; (11) cooperating in the fight against crime and terrorism; and (12) delivering a smooth, orderly exit from the EU.

43 Article 1, section 2 of the Brexit Bill, as amended by the House of Lords, prescribes as follows:

Within three months of exercising the power under subsection (1), Ministers of the Crown must bring forward proposals to ensure that citizens of another European Union or European Economic Area country and their family members, who are legally resident in the United Kingdom on the day on which this Act is passed, continue to be treated in the same way with regards to their EU derived-rights and, in the case of residency, their potential to acquire such rights in the future.

44 Lords Divisions results, March 1, 2017-Division 1, European Union (Notification of Withdrawal) Bill, available at http://www.parliament.uk/business/publications/business-papers/lords/lords-divisions/?date=2017-Mar01\&itemId=1\&session=2016-May-18 (last visited on Apr. 10, 2017).

45 House of Commons, Monday 13 March, 2017, Votes and Proceedings, No. 123, available at https://www.publications. parliament.uk/pa/cm201617/cmvote/170313v01.pdf (last visited on Apr. 10, 2017).

46 Lords Divisions results, March 13, 2017-Division 5, European Union (Notification of Withdrawal) Bill, available at http:/www.parliament.uk/business/publications/business-papers/lords/lords-divisions (last visited on Apr. 10, 2017).

47 See Brexit: Theresa May's Article 50 launch trashed after top EU politicians reject key demands, INDEPENDENT, Mar. 


\section{Brexit: Implications for the Expansion and Advancement of European Integration}

\section{A. National Sovereignty v. the Exercise of the EU's Competences}

Sovereignty is a critical factor that constitutes a nation, along with the people and territory. It refers to supremacy, independence, and absolute power to finally decide the will of the state. In modern times, sovereignty has been recognized as "national sovereignty,' having the qualities of "inalienability, inviolability and absolute power" in relations with a third country. ${ }^{48}$

However, the EEC, which was launched as "new legal order in the international order," 49 created its own legal system. In particular, as Churchill argued, the EEC aimed for a "European Political Community" modeled upon the US federalism. ${ }^{50}$ Indeed, there was an active discussion about the legal and political status of the EEC. Consequently, the concept of "super-nationality or supranationality," which can be summarized as "the EEC has a supranational status," was established. ${ }^{51}$ While specifically interpreting and applying this concept in the process of European integration, it is important to find how to address the conflict and harmony between "sovereignty and supranationality." This can be closely examined by taking the EU's competence as an example.

In its judgment in Van Gend en Loos on February 5, 1963, the ECJ emphasized: "The EC constitutes a new order of international law. Therefore, the member states shall limit their sovereign rights." ${ }^{52}$ As seen in this judgment, for the EEC to form and function properly as a "new order of international law," it is inevitable that the 'sovereign rights' of the member States will be limited. In that sense, the relationship

29, 2017, available at http://www.independent.co.uk/news/uk/politics/brexit-latest-article-50-theresa-may-eu-angelamerkel-security-divorce-bill-a7657116.html (last visited on Apr. 10, 2017).

48 J. Combacau \& S. Sur, Droit International Public 234-6 (2e ed. 1995).

49 Case 26/62 van Gend en Loos v. Nederlandse Administatie der Belastngen [1963] ECR 1, at 12.

50 Winston Churchill gave the following speech on September 19, 1946 at the University of Zurich:

We must build a kind of United States of Europe. In this way only will hundreds of millions of toilers be able to regain the simple joys and hopes which make life worth living. The structure of the United States of Europe, if well and truly built, will be such as to make the material strength of a single state less important. Small nations will count as much as large ones and gain their honor by their contribution to the common cause."

The whole text of the speech can be available at http://www.churchill-society-london.org.uk/astonish.html (last visited on Apr. 10, 2017).

51 J. Ruszkowski, Supranationalism between the nation-state and international cooperation, 1 J. PuBlic Administration \& Pol'y Res. 5 (May 2009).

52 Case 26/62 van Gend en Loos v. Nederlandse Administatie der Belastngen [1963] ECR 1, at 12. 
between the EEC and the member States should be established, as the key to defining the principles concerning the competence exercised by the EEC.

Article 5 of TEU stipulates that: "The limits of Union competences are governed by the principle of conferral." In accordance with the "principle of conferral," TFEU divides the EU's competences into five categories: (1) exclusive competence; ${ }^{53}$ (2) shared competence; ${ }^{54}$ (3) supported competence; ${ }^{55}$ (4) competence to implement a common foreign and security policy; ${ }^{56}$ and (5) competence of coordination. ${ }^{57}$ In addition, the flexibility clause, ${ }^{58}$ the principle of proportionality, ${ }^{59}$ and the principle of subsidiarity ${ }^{60}$ all supplement these competences.

Thus, the type and applicable scope of the EU's competences have been defined according to the principle of conferral. However, proper application of this principle depends on how, and how properly, the distributed competences are reflected and exercised in actual policies.

Regarding the exclusive competence, e.g., this allows the EU to act on its own for the benefit of its member States. This competence is usually implemented in the form of a 'common policy' such as the Common Agricultural Policy ("CAP") and the Common Commercial Policy ("CCP”). In the given policy areas, the sovereignty of the member States involved is transferred to the EU. Regarding CAP, e.g., if a principle of the common policy on agriculture is defined at the EU level, the member States should establish and implement domestic policy accordingly. As sovereignty over agriculture has been transferred to the EU, member States are not allowed to exercise the competence to establish and implement policies independently. This means that while the exercise of national sovereignty is limited, the EU's competences are extended.

The issue of conflict and harmony between the exercise of sovereignty by member States and the EU's competences is not raised only in the exercise of exclusive competence. Numerous conflicts also emerge in the process of exercising and implementing other competences. In particular, there have been many controversies over application of the principle of subsidiarity, as well as the competence to implement a common foreign and security policy. Perhaps such

53 TFEU art. $2, \S 1$.

54 Id. art. $2, \S 2$.

55 Id. art. $2, \S 3$.

56 Id. art. $2, \S 4$.

57 Id. art. $2, \S 5$.

58 Id. arts. $2, \S 6$; \& 352, §§ 1-2.

59 TEU art. $5, \S 3$.

$60 \quad$ Id. art. $5 \S 4$. 
issues are unavoidable for the EU, given its status as a quasi-federal state. The UK has long been in conflict with the EU over the free movement of persons throughout the Eurozone and the Schengen Agreement. In recent, the disagreements are even escalating, especially due to recent immigration and refugee policies. As can be seen from the fact these eventually caused by the Brexit decision, the EU must now more deeply consider how to exercise the competences granted to itself in harmony with the sovereignty of member States. In addition, this can be regarded as a measure of the success or failure of the European Single Market through the expansion and advancement of European integration.

\section{B. Problem of Social Democratic Deficit}

Since the establishment of the EEC, in principle, it has pursued 'social Europe' by implementing a so-called "socio-economic convergence" that integrates social and economic policies, centered on free movement of workers. This spirit continues until today and is also confirmed in the full text of the TEU. ${ }^{61}$

However, as the European integration progressed and multi-layered governance became established, the issue of 'democratic deficit' has constantly been raised in the EU's decision-making process. A closer look at this issue in relation to social Europe reveals that it leads to the "social democratic deficit." In the course of deepening and enlargement of European integration, the power of financial capital has progressed, so that full-scale industrial restructuring by companies became routine, resulting in the soaring number of 'precariats,' referring to precarious workers. Consequently, workers and labor unions in favor of the construction of social Europe were excluded and marginalized from the integration process, which eventually caused the problems of the social democratic deficit. ${ }^{62}$

High profile of social welfare is a fundamental mechanism which distinguishes the Western Europe from other regions such as Asia and the Americas. Today,

61 Regarding social Europe, the TEU Preamble (referring to the EU's member states) prescribes as follows:

- CONFIRMING their attachment to fundamental social rights as defined in the European Social Charter signed at Turin on 18 October 1961 and in the 1989 Community Charter of the Fundamental Social Rights of Workers,

- DETERMINED to promote economic and social progress for their peoples, taking into account the principle of sustainable development...

- RESOLVED to facilitate the free movement of persons, while ensuring the safety and security of their peoples, by establishing an area of freedom, security and justice, ...

- RESOLVED to continue the process of creating an ever-closer union among the peoples of Europe, in which decisions are taken as closely as possible to the citizen in accordance with the principle of subsidiarity, 
however, the unemployment rate of young adults and middle-aged people has been increasing due to the long-term economic downturn and recession. In the current situation, a critical question - Are the values and ideologies of social Europe serve the absolute good? - is arising in the majority of member states, including the UK. Therefore, the EU must reconsider how to eliminate the problems of 'democratic deficit' in the process of establishing and implementing policies on social Europe. In terms of building social Europe, Brexit would become either a poisoned chalice or a good medicine for the EU. ${ }^{63}$

\section{Problem of "United in Diversity" v. 'Europeanization'}

The EU's motto is "United in Diversity." 64 The EU, a regional community of 28 member States, has implemented policies pursuing universality or unity at the European level, based on respect for the various traditions, histories, and cultures of each country. However, it is difficult to harmonize "diversity and universality" with "unity (or unicity) and regionality" because they are conflicting concepts. Therefore, the EU has advanced the "acquis communautaire (Community acquis)" and adopted the concept of the "common heritage of the EU," which collectively considers the values, ideologies, and legal system accumulated from its establishment to the present. $^{65}$

In addition, the motto, "United in Diversity" is closely related to 'Europeanization,' the ideals of Europe pursued by the EU. This expression can be understood to convey Western Europe's own globalization strategy, while accepting globalism or

63 K. Lörcher \& I. Schömann, The European pillar of social rights: critical legal analysis and proposals, ETUI Research Paper Report No. 139, 124 (2016), available at https://papers.ssrn.com/sol3/papers.cfm?abstract_id=2859976 (last visited on Apr. 10, 2017)

64 For details on the EU's motto, see EU, The EU Motto, available at https://europa.eu/european-union/about-eu/symbols/ motto_en (last visited on Apr. 10, 2017).

65 Acquis communautaire refers to "the body of common rights and obligations that is binding on all the EU member states" and applies to every EU law and policy. In particular, the following are bound by acquis communautaire:

- the content, principles, and political objectives of the Treaties;

- legislation adopted pursuant to the Treaties and the case law of the Court of Justice;

- declarations and resolutions adopted by the Union;

- instruments under the Common Foreign and Security Policy;

- international agreements concluded by the Union and those entered into by the member states among themselves within the sphere of the Union's activities.

Candidate countries wishing to join the EU are required to accept acquis communautaire into their domestic law to obtain the status of a member State. For details, see European Commission, Enlargement - Acquis, available at https://ec.europa.eu/neighbourhood-enlargement/policy/glossary/terms/acquis_en. See also House of Commons, The EU's Acquis Communautaire, SN/IA/5944, Apr. 26, 2011, available at http://researchbriefings.files.parliament.uk/ documents/SN05944/SN05944.pdf (all last visited on Apr. 10, 2017). 
internationalization. This is, in other words, the "glocalization of Europe." provides extensive details on the "ideals of Europe" as follows: (1) the cultural, religious, and humanist inheritances of Europe, which have developed the universal values of the inviolable and inalienable rights of the human person, freedom, democracy, equality, and the rule of law; (2) the historic importance of the ending of the division of the European continent and the need to create firm bases for the construction of the future Europe; and (3) the principles of liberty, democracy, and respect for human rights, fundamental freedoms, and the rule of law. ${ }^{67}$

However, it is evident from the Brexit case, the European values and ideologies are now facing a serious crisis under both globalization and nationalism. The relationship between the UK and the EU will be reestablished in accordance with the future political and economic situations globally and in Europe and the outcome of the Brexit negotiations. Furthermore, the possibility of the additional and sequential withdrawal of other member States cannot be excluded. In any case, Brexit will become a touchstone for judging the success or failure of the EU as a political system beyond the State.

\section{Conclusion}

How should Brexit be evaluated? Put simply, the UK has opted for a return to nationalism based on sovereignty, rather than regional peace and coexistence through European integration and the European Single Market. It is clear that Brexit has given un coup dur to the EU, which pursues a single, integrated Europe. Then, is the UK coupable in this choice?

In reality, the rapid expansion of Europe from the establishment of the EEC to today's EU has given its member States and their citizens a sense of fatigue that has gradually accumulated. Furthermore, the EU and its member States have long been in a bitter tug-of-war, confronting or cooperating with each other over the general interests of Europe and the interests of individual nations. It is also true that some members, such as Greece and Italy, have also seriously considered withdrawing from the EU, while experiencing global financial crisis. Brexit is the first case of withdrawal. In this situation, who is entitled to cast a stone in the UK?

66 For details, see R. Robertson (ed.), European Glocalization in Global Context 225 (2014).

67 TEU pmbl. 
After the UK's withdrawal from the EU is completed, how will Europe approach the future? With Brexit, the EU may enter a new phase of reorganizing institutions and systems. Despite several different criticisms, the EU is the most advanced and developed model of its kind globally. European citizens have their own identity and bond as a community of shared destiny. Since the launch of the EEC, severe civil wars within or wars between member States have not occurred, and the lives of European citizens have been stable and at a qualitatively higher level, with basic human rights and peace both secured.

However, Britain which has continued to show confusing attitudes toward European policies since joining in the EEC, raised the stakes by opting for withdrawal from the EU. Britain, a powerful and developed country, both past and present, chose to return its State sovereignty rather than pursue cooperation and solidarity in regionalism. There is great concern that the UK's decision could project Europe and other countries into competing relationships again. In any sense, Britain, having decided to pursue Brexit, will not be free from criticism over its return to nationalism. 
